\title{
Benthos monitoring in Red Sea, Egypt \\ A- The western coast of the Suez Gulf
}

\author{
Mohamed M. EI Komi ${ }^{1}$ and Ahmed M. Emara ${ }^{2}$ \\ 1- National Institute of Oceanography and Fisheries, Alexandria, Egy" \\ Komi mohamed50@yahoo.com \\ 2-National Institute of Oceanography and Fisheries, Red Sea and Suez \& . a \\ Gulfs Brancl, Suez, Egypt.
}

\begin{abstract}
耳ourteen macrobenthic groups of identified taxa were involved witl: ive C main higher taxonomic levels on 15 monitoring sites at the western curist of the Gulf of Suez during one year (2000) with an average of $125 \mathrm{ind} . / \mathrm{m}^{2}$. These levels included Polychaeta (81.0\%), Crustacea (5.7\%) (Decapoda, Cumacea, Amphipoda and Anisopoda), Mollusca (7.01\%) (Scaphopoda, Gastropoda and Bivalvia), Echinodermata (0.60\%) (Echinoidea and Ophiuroidea) and the other minor groups $5.8 \%$ (Nematoda, Hydroids, Bryozoa, and Cephalochordata). The density and diversity of marine benthos were higher on hard and cobble bottoms compared to muddy sand substrates. The changes in benthic fauna structures in the sandy area depend not only on the state of pollution, but also on the type of substrate. The benthic fauna assemblages were dominated by polychaetes, which showed the highest density, reaching $81.0 \%$ of total density. Polychaete species were more frequent at nearly all sites. The dominant family was Capitellidae, being recorded at 4 sites among benthic fauna of total density. Bivalves were less abundant $(6.53 \%)$ though Tellinella staurella had the maximum occurrence at 4 sites, yielding a total of $70 \mathrm{ind} / \mathrm{m}^{2}$. (52\%) followed by Nematoda, Anisopoda and Amphipoda reached 3.75, 2.30 and $1.80 \%$, while Decapoda and Bryozoa were represented $1.23 \%$ \&.1.23\% of the total density respectively. The percentage of abundance of benthic groups at higher taxonomic levels in the sampling sites along the western coast of Suez Gulf can be arranged in the following sequence: polychaetes $(81.0 \%)>$ molluscs $(7.01 \%)>$ other groups $(5.8 \%)>$ crustaceans $(5.7)>$ echinoderms $(0.60 \%)$. The composition of benthos in the study area is affected by a complex interaction of environmental parameters, which can be grouped into physical and biological parameters as well as pollution.
\end{abstract}

Key words: Benthos, pollution, biomass, sediment, Suez Gulf.

\section{INTRODUCTION}

The Suez Gulf is a large semi-closed area, with a $346 \mathrm{~km}$ long coastline on the western beach side of the Gulf. It has an approximate surface area of $10,510 \mathrm{~km}^{2}$, with a shallow flat bottom relative to the Red Sea and Aqaba Gulf, with depths not exceeding $90 \mathrm{~m}$ (Badr and Crossland, 1939; Nawar, 1981). It is a 
major international route for oil transportation and merchant marine shipping from the Red Sea to the Mediterranean Sea and the reverse. Recently, the marine life in the western coast of the Suez Gulf is threatened by the increase of various economic activities. The various man-made activities have an impact or different stresses on the reproductive capacity of species, while the coastal development constructions cause mortality for the benthic organisms. Therefore, the status of bio-diversity of such marine ecosystem can be obtained through indicator species. For this purpose, the following monitor has been selected, namely benthic community.

In general "benthos" is important in the ecosystem which has a wide variety in the species composition of mainly polychaete worms, molluscs, echinoderms, and crustaceans living in burrows in the sediment (infauna) or on the sediment surface (epifauna). It represents a food source for many species of commercially exploited fish and crustaceans and for many species of seabirds.

Many structures and facilities along the coastline of the Gulf of Suez were constructed such as oil production at the middle part and the tourism projects at the most southern and northern parts. Hargrave and Thiel (1983), Hartnail (1984), El-Komi (1997) and El-Komi \& Beltagy (1997) reviewed the impact assessinent of pollution on the benthic structure and studied the distribution of the macrobenthos assemblages in the shallow intertidal zone along the western coast of the Gulf of Suez, Egypt.

Analysis of macobenthic infauna is essential for marine environmental monitoring programmes, because macrobenthos provide valuable information that cannot otherwise be obtained (Bilyard, 1987). A lot of studies about the impacts of physical disturbance on benthic organisms and their recovery have been done. Kenny \& Rees (1994) found significant reduction in the variety, abundance and biomass of benthic organisms as a consequence of dredging in United Kingdom.

This study is a part of framework of the EIMP Coastal Monitoring Program including "Benthos monitoring" on 15 monitoring sites at the western coast of the Gulf of Suez once a year. Its main objective is studying the impact assessment of coastal development in Egypt of the various activities included in any coast project and the causal relationslips between pollution and adverse impact on benthos including the interpretation of such adverse effects. Therefore, the composition of benthos on a site reflects the sum of effects, which environmental factors have on each individual during a longer period and minimizing the adverse impact particularly on the marine ecosystem.

\section{MATERIALS AND METHODS}

Monitoring of macrobenthic fauna of the Egyptian coasts was examined at 15 sites in the coastal waters of the western side of the Suez Gulf during October-November 2000 through field trips in the study area. The position of the selected sites was detected by using GPS as shown in Fig. (1). 


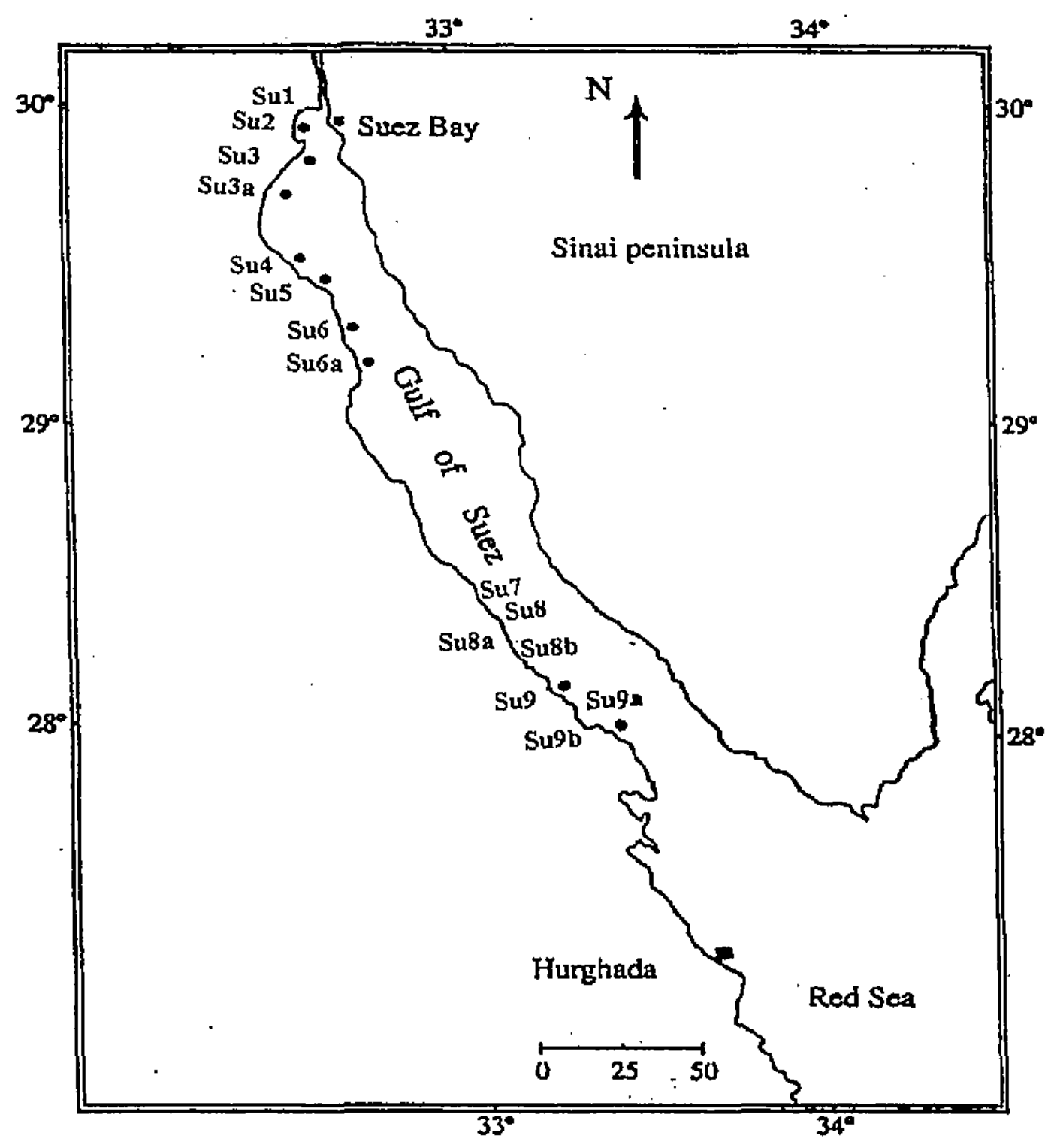

Fig. (1): Location of sampling sites in the Western Coast of the Gulf of Suez.

\section{Study area:}

Western coast of the Suez Gulf:

It lies at lat. $29^{\circ} 56^{\prime} 35^{\prime \prime} \mathrm{N}$, long. $32^{\circ} 30^{\circ} 42^{\prime \prime}$ E to lat $28^{\circ} 06^{\prime} 58^{\prime \prime} \mathrm{N}$, long. $33^{\circ} 17^{\circ} 50^{\prime}$ E. Su1-Suez Bay, Su2-Suez Bay (NIOF), Su3-Suez Bay, Su3aSuez, Su4-Ain Sukhna, Su5-Ain Sukhna, Su6-Abu Darag, Su6a-Wady el Dom, Su7-Ras Gharib, Su8-Ras Gharib, Su8a-Ras Gharib, Su8b-Ras Gharib, Su9-Ras Shukier, Su9a-Ras Shukier and Su9b-Ras Shukier.

At each sampling site a quantitative survey of the macrobenthos communities was conducted from the upper layer by using Van Veen grab 
sampler (equivalent to $0.1 \mathrm{~m}^{2}$ ). Three benthos samples were collected by using a fishing boat with a winch wire from depth ranged from 5 to 10 meters. The collected sample was washed on the board through a sieve with mesh size $1 \mathrm{~mm}$ and the residue was preserved in $5-10 \%$ formalin solution.

In the laboratory, the sample was washed thoroughly and sorted to their main constituents. Each group was identified to the species or the genus levels, counted and weighed. Quantitative analysis of the-macro benthos communities was carried out; in order to estimate the density and abundance of each species as the number of organisms per $\mathrm{m}^{2}$ and the corresponding biomass of their main groups were expressed as the wet weight in gram per $\mathrm{m}^{2}$.

Statistical analysis of benthic community structure included the following descriptive measurements, which were computed at each site:

a) The Shannon-Weaver (1949) index $\mathrm{H}=-\sum P i \log _{e} P i \quad$ where $P i=$ Proportional of a sample of individuals belonging to species.

b) Species richness as Margalef (1958) 's index $\mathrm{J}=(\mathrm{S}-1) / \log _{e} N$ where $N=$ the number of individuals in a sample and $S$ is the species number per sample.

c) Evenness was calculated as Pielou (1966) 's index $\mathrm{E}=\mathrm{H}^{\prime} / \mathrm{Hmax}=\mathrm{H}^{\prime} / \operatorname{loge} \mathrm{S}$ where $S=$ the number of species in a sample.

d) Evaluate the dominance of Simpson (1949)'s index $\mathrm{D}=1-\sum P i^{2}$

e) According to Pearson and Rosenberg (1978) the ratios B/A and A/S were plotted for the samples at the different sites.

f) The triangular matrix of similarities between samples leading to: hierarchical classification (cluster analysis) (FAO, 1991). This was based on a Bray-Curtis similarity matrix of appropriately transformed species abundance or biomass data.

\section{Nature of bottom}

\section{RESULTS}

Four types of bottom sediments were recorded along the coastal area of the western side of the Suez Gulf at different sampling sites. Each of the coarse and muddy sand bottom was represented by $13 \%$ of the number of sites, while the medium and fine sand recorded higher values of $41 \%$ and $33 \%$ respectively. As shown in Fig. (2), these types as reported in EIMP (2000) are:

1) Coarse sand (0.08 to 0.32 ф) at sites Su7 (Ras Gharib) and Su9a (Ras Shukier).

2) Medium sand (1.97 to 1.43 ф) at sites Su2 (Suez Bay, NIOF), Su3 (Suez Bay), Su 3a (Suez), Su 6a (Wady el Dom), Su8b (Ras Gharib) and Su9b (Ras Shukier).

3) Fine sand (2.53 to 2.06 ) at sites Su4 (Ain Sukhna), Su6 (Abu Darag), Su8 (Ras Gharib), Su8a (Ras Gharib) and Su9 (Ras Shukier).

4) Muddy sand (6.66 to 3.02 ф) at sites Sul (Suez Bay, NIOF) and Su5 (Ain Sukhna). 


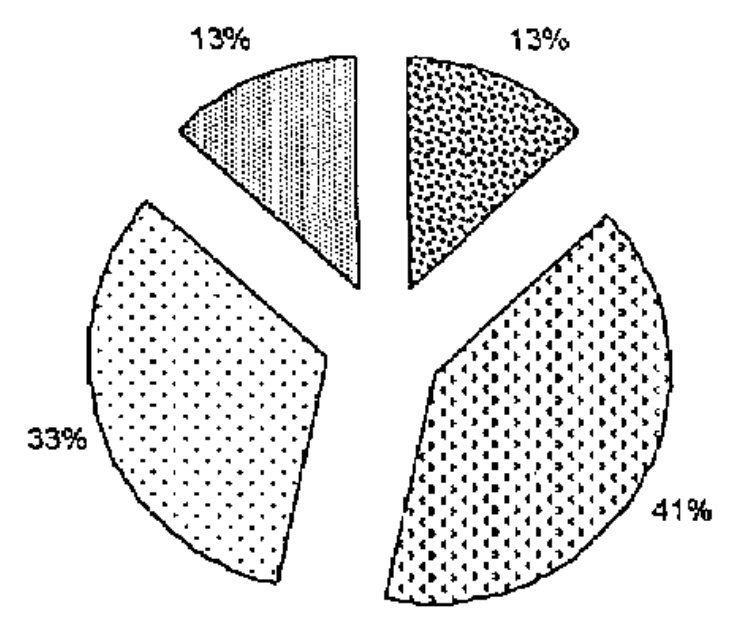

a Coarse sand $\square$ Medium sand $\square$ Fine sand a Muddy sand

Fig. (2): Percentage of types of bottom substrata recorded at different sampling sites along the western coast of the Gulf of Suez during 2000.

Structure of benthos assemblages

The density of benthos at different sampling sites reached 125 ind $/ \mathrm{m}^{2}$ in average, where 14 benthic groups were identified (Table 1). These included Nematoda, Hydroids, Polychaeta, Decapoda, Cumacea, Amphipoda, Anisopoda, Scaphopoda, Gastropoda, Bivalvia, Bryozoa, Echinoidea, Ophiuroidea, and Cephalochordata. These groups belong to five main higher taxonomic levels namely: class Polychaeta; class Crustacea (Decapoda, Cumacea, Amphipoda and Anisopoda); phylum Mollusca (Scaphopoda, Gastropoda and Bivalvia); phylum Echinodermata (Echinoidea and Ophiuroidea) and other minor groups (Nematoda, Hydroids, Bryozoa and Cephalochordata). Species numbers (S):

A total of 60 species were identified among the bulk of macrobenthic communities at the different sampling sites, where the general structure of species was composed mainly of Polychaeta sustaining $58.3 \%$ of the total number of species. It was followed by Bivalvia (10.3\%), Decapoda (6.7\%) Echinoidea (5.2\%), Amphipoda (3.3\%) and Gastropoda (3.3\%).

As shown in Table (3), the highest number of species was 16 species at Suez (Su 3a) followed by 12 species at Ain Sukhna (Su4) and 10 species at Ras Gharib (Su7). The species numbers were less frequent at the sites Su2 (NIOF, Suez Bay), Su3 (Suez Bay) and Su5 (Ain Sukhna), where the range was 9-10 species. 
Table (1 ): Regional distribution of species of benthos density (no. of individual $/ \mathrm{m}^{2}$ ) at the different sampling sites along the coastal waters of the Gulf of Suez during October, 2000.

\begin{tabular}{|c|c|c|c|c|c|c|c|c|c|}
\hline Groups / Stalions & Su: & $S_{1} 2$ & Suj & Su $3 a$ & Su 4 & Sus & S. 6 & S.] ba & Su 7 \\
\hline Nematoda & $\eta$ & D & 0 & 0 & 0 & 0 & 0 & 0 & 70 \\
\hline Hydroida & 3 & 0 & 0 & 0 & 0 & 0 & 0 & 0 & 0 \\
\hline Pólychasa & 84 & 376 & 440 & 175 & 66 & 282 & 0 & 0 & 42 \\
\hline Decapoda & 7 & 10 & 0 & 0 & 0 & 3 & 0 & 3 & 0 \\
\hline Cumacea & 0 & 0 & 0 & 0 & 0 & 0 & 0 & 0 & 7 \\
\hline Amplipoda & 3. & 0 & 0 & 3 & 0 & 10 & 0 & 0 & 0 \\
\hline Anisopcda & 0 & 33 & 7 & 0 & 0 & 3 & 0 & 0 & 0 \\
\hline Scapliopoda & 0 & 1] & 3 & 0 & 0 & 0 & 0 & 0 & 0 \\
\hline Gastropoda & 0 & D & 0 & 0 & 0 & 0 & 0 & 3 & 0 \\
\hline Bivalvia & 23 & 0 & 30 & 30 & 3 & 0 & 0 & 3 & 0 \\
\hline Bryozoa & 20 & 0 & 0 & 0 & 3 & 0 & 0 & 0 & 0 \\
\hline Ech:noidza & 0 & 0 & 0 & 0 & 6 & 0 & 0 & 0 & 0 \\
\hline Oplajuroidea & 0 & 3 & 0 & 3 & 0 & 0 & 0 & 0 & 0 \\
\hline Ceplalochordata & 0 & 0 & 0 & 10 & 0 & 0 & 0 & 0 & 0 \\
\hline Tolal nc, ind $r \mathrm{~m}^{2}$ & $\$ 37$ & 422 & 480 & 221 & 78 & 298 & 0 & 9 & 119 \\
\hline No. of sp./station & 6 & 10 & 10 & 16 & 13 & 9 & 0 & 3 & 10 \\
\hline \%or total abund & $7.31 \%$ & $22.51 \%$ & $25.60 \%$ & $11.79 \%$ & $4.16 \%$ & $5.89 \%$ & $0.0 \%$ & $0.48 \%$ & $6.35 \%$ \\
\hline
\end{tabular}

\begin{tabular}{|c|c|c|c|c|c|c|c|c|}
\hline Groups / Stacions & Su 8 & Su $8 \mathrm{a}$ & Su g o & Su 9 & Su $9 a$ & St9b & Average & $\%$ \\
\hline Nematoda & 0 & 0 & 0 & 0 & 0 & 0 & 4.7 & $3.7 \%$ \\
\hline Jydroids & 0 & 0 & c & 0 & 0 & 0 & 0.2 & $0.2 \%$ \\
\hline Poigyclnact & 10 & 6 & 13 & 3 & 7 & 10 & 101 & $81 \%$ \\
\hline Decopoda & 0 & 0 & 0 & 0 & 0 & 0 & 1,5 & $1.2 \%$ \\
\hline Cumacea & 0 & 0 & 0 & 0 & 0 & 0 & 0.5 & $0.4 \%$ \\
\hline Amphipada & 0 & 20 & 0 & 0 & 0 & 0 & 2.2 & $1.8 \%$ \\
\hline Anisopoda & 0 & 0 & 0 & 0 & 0 & 0 & 2.9 & $2.3 \%$ \\
\hline Scaphopoda & 0 & 0 & 0 & 0 & 0 & 0 & 0.2 & $0.2 \%$ \\
\hline Gastropoda & 0 & 0 & 0 & 3 & $D$ & 0 & 0.4 & $0.3 \%$ \\
\hline Biyalvia & 0 & 30 & 0 & 0 & D & 3 & 8.1 & $6.5 \%$ \\
\hline Bryozoa & 0 & 0 & 0 & 0 & 0 & 0 & 1.5 & $1.2 \%$ \\
\hline Echinoidea & 0 & 0 & 0 & 0 & D & 0 & 0.4 & $0.3 \%$ \\
\hline $\begin{array}{l}\text { Ophiuroiden } \\
\text { Cephalochordata }\end{array}$ & $\begin{array}{l}0 \\
0\end{array}$ & $\begin{array}{l}0 \\
0\end{array}$ & $\begin{array}{l}0 \\
0 \\
\end{array}$ & $\begin{array}{l}\mathbf{0} \\
\mathbf{0}\end{array}$ & $\begin{array}{l}0 \\
0 \\
\end{array}$ & $\begin{array}{l}0 \\
0 \\
\end{array}$ & $\begin{array}{l}0.4 \\
0.7\end{array}$ & $\begin{array}{l}0.3 \% \\
0.5 \% \\
\end{array}$ \\
\hline Iotal no ind. $/ \mathrm{m}^{2}$ & 10 & 56 & 13. & 6 & 7 & 13 & 125 & $100 \%$ \\
\hline No, of $\mathrm{sg} /$ station & 2 & 5 & 1 & 2 & 2 & 2 & & \\
\hline$\%$ f tolal abund & $0.53 \%$ & $2.99 \%$ & $0.69 \%$ & $0.32 \%$ & $0,37 \%$ & $0.69 \%$ & & \\
\hline
\end{tabular}

\section{Abundance (A):}

Polychaetes showed the highest density of individual numbers, accounting for $81.0 \%$ of the total number of individuals (Table 2 and Fig. 4). The average density of benthic groups was encountered by $125 \mathrm{ind} . / \mathrm{m}^{2}$. Bivalves were less abundant (6.53\%) followed by Nematoda, Anisopoda, Amphipoda and 
(Decapoda \& Bryozoa) which reached $3.75,2.30,1.80 \%$ and $(1.23 \% \& .1 .23 \%)$ of the total density respectively as listed in Table (I). The percentage of abundance of benthic groups at higher taxonomic levels at the sampling sites along the western coast of the Suez Gulf can be arranged in the following sequence: polychaetes $(81.0 \%)>$ malluses $(7.01 \%)>$ other groups $(5.8 \%)>$ crustaceans $(5.70 \%)>$ echinoderms $(0.60 \%)$.

Table (2): Regional distribution of species of benthos density (no. of individual $i \mathrm{~m}^{2}$ ) nt the different sampling sites along the coastal waters of the Gulf of Suez duling October, 2600.

Western const of the Gulf of Suez

\begin{tabular}{|c|c|c|c|c|c|c|c|c|c|}
\hline $\begin{array}{l}\text { Croups } 1 \\
\text { Stations }\end{array}$ & $\mathrm{Su} 1$ & Su 2 & Su 3 & $\begin{array}{l}\text { Su } \\
3 \mathrm{a}\end{array}$ & $S \sqcup 4$ & Su 5 & Su 6 & Su $6 a$ & Su 7 \\
\hline Polychaeta & 84 & 376 & 440 & 175 & 66 & 282 & 0 & 0 & 42 \\
\hline Crustacea & 7 & 43 & 7 & 3 & 0 & 16 & 0 & 3 & 7 \\
\hline Mollusca & 23 & 0 & 33 & 30 & 3 & 0 & 0 & 6 & 0 \\
\hline Echinociermata & 0 & 0 & 0 & 3 & 6 & 0 & 0 & 0 & 0 \\
\hline Other groups & 23 & 3 & 0 & 10 & 3 & 0 & 0 & 0 & 70 \\
\hline $\begin{array}{l}\text { Total no. } \\
\text { ind. } / \mathrm{m}^{2}\end{array}$ & 137 & 422 & 480 & 221 & 78 & 298 & 0 & 9 & 110 \\
\hline $\begin{array}{c}\text { No. of sp. } / \\
\text { station }\end{array}$ & 6 & 10 & 10 & 16 & 13 & 9 & 0 & 3 & 10 \\
\hline $\begin{array}{l}\% \text { f total } \\
\text { abund. }\end{array}$ & $\begin{array}{c}7.31 \\
\% \\
\end{array}$ & $\begin{array}{c}22.51 \\
\% \\
\end{array}$ & $\begin{array}{c}25.6 \\
\% \\
\end{array}$ & $\begin{array}{c}11.8 \\
\% \\
\end{array}$ & $\begin{array}{c}4.16 \\
\% \\
\end{array}$ & $\begin{array}{c}15.89 \\
\% \\
\end{array}$ & $\begin{array}{c}0.00 \\
\% \\
\end{array}$ & $\begin{array}{c}0.48 \\
\% \\
\end{array}$ & $\begin{array}{c}6.35 \\
\% \\
\end{array}$ \\
\hline $\begin{array}{l}\text { Groups / } \\
\text { Stations }\end{array}$ & Su 8 & Su $8 \mathrm{a}$ & Su $8 b$ & Su 9 & Su 9a & Sugb & Average & $\%$ & \\
\hline Polychaeta & 10 & 6 & 13 & 3 & 7 & 10 & 101 & $80.7 \%$ & \\
\hline Crustacea & 0 & 20 & 0 & 0 & 0 & 0 & 7 & $5.7 \%$ & \\
\hline Mollusca & 0 & 30 & 0 & 3 & 0 & 3 & 9 & $7.0 \%$ & \\
\hline Echinodermata & 0 & 0 & 0 & 0 & 0 & 0 & 1 & $0.5 \%$ & \\
\hline Other groups & 0 & 0 & 0 & 0 & 0 & 0 & 7 & $5.8 \%$ & \\
\hline $\begin{array}{c}\text { Total no. ind. I } \\
\mathrm{m}^{2}\end{array}$ & 10 & 56 & 13 & 6 & 7 & 13 & 125 & $100 \%$ & \\
\hline $\begin{array}{c}\text { No. of sp.l } \\
\text { station }\end{array}$ & 2 & 5 & 1 & 2 & 2 & 2 & & & \\
\hline$\%$ of total abund. & $\begin{array}{c}0.53 \\
\% \\
\end{array}$ & $\begin{array}{c}2.99 \\
\%\end{array}$ & $\begin{array}{c}0.69 \\
\%\end{array}$ & $\begin{array}{c}0.32 \\
\%\end{array}$ & $\begin{array}{c}0.37 \\
\%\end{array}$ & $\begin{array}{c}0.69 \\
\%\end{array}$ & & & \\
\hline
\end{tabular}


(A):

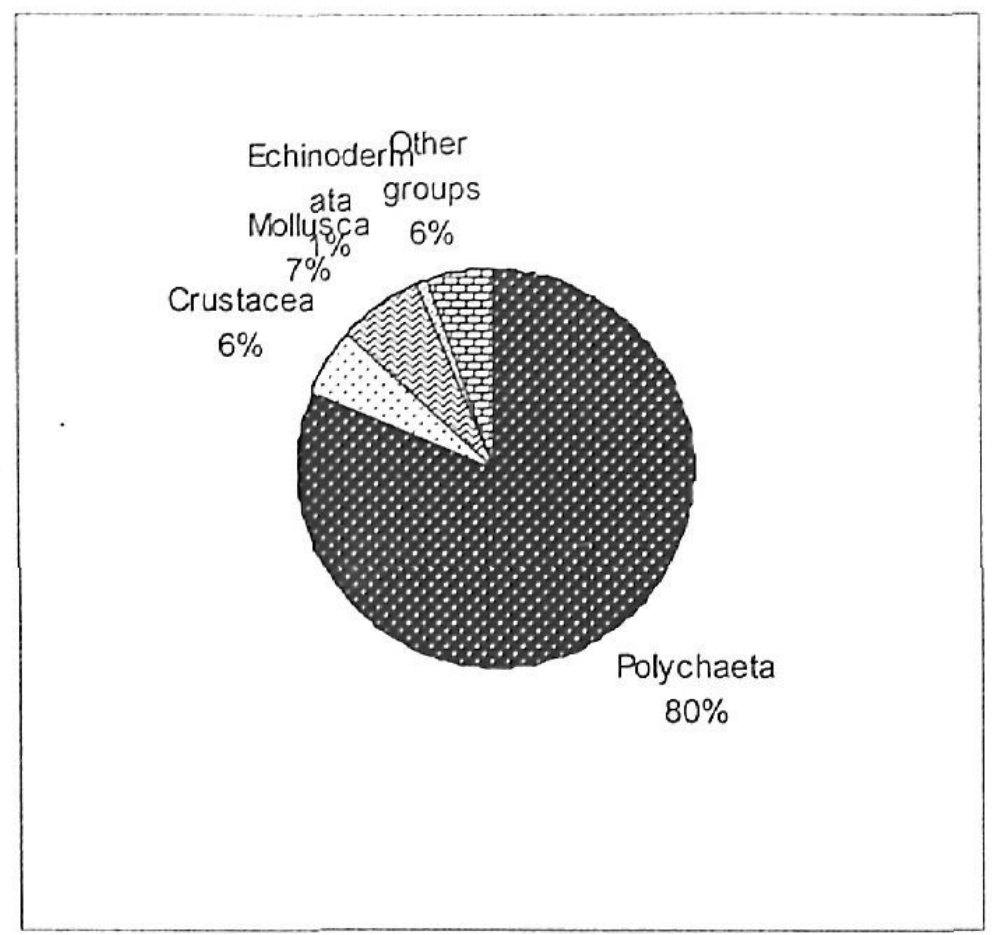

(B):

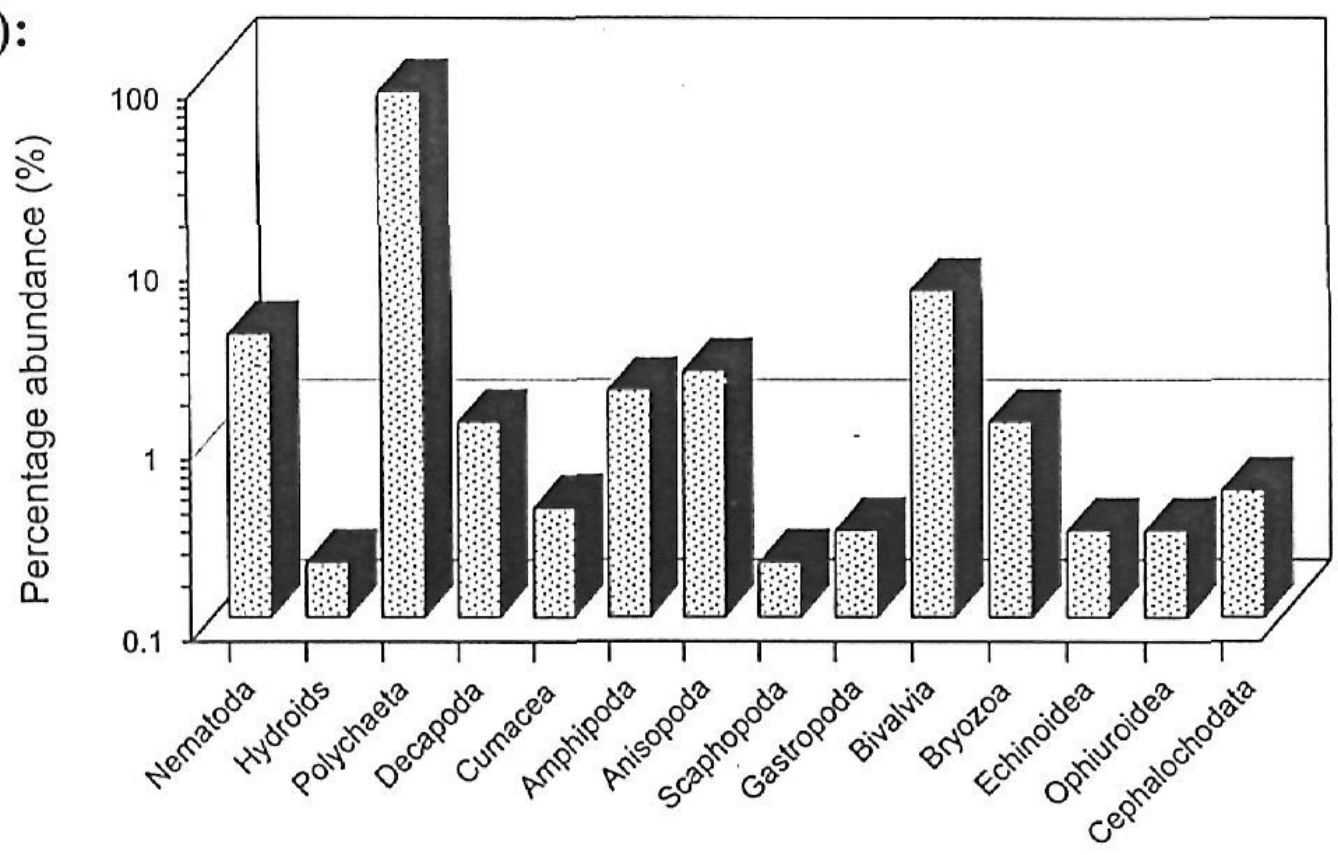

Groups

Fig. (4): (A \& B): Variations percentage of abundance (no. ind. $/ \mathrm{m}^{2}$ ) of the benthic groups at the different sites along the western coast of Suez Gulf during 2000.

Biomass (B):

Echinoidea group showed the largest intensity $\% 58.53$ of the total bulk of benthos collected at the different sites, (Table 3). Meanwhile, Bivalvia and 
Polychaeta species were relatively less frequent, yielding $4.2 \mathrm{~g} / \mathrm{m}^{2}$ and $1.7 \mathrm{~g} / \mathrm{m}^{2}$ in average, representing $18.60 \%$ and $19.0 \%$ respectively of the total biomass, (Fig. 6). The biomass of Decapoda, Gastropoda and Amphipoda groups showed the least occurrence.

Table (3): Regional dist:ibutions of groups of benthos biomass $\left(\mathrm{g} / \mathrm{m}^{2}\right)$ at the different sampling sites along the coastal waters of the Gulf of Suez during Oclober, 2000.

Western const of the Gull of Suez

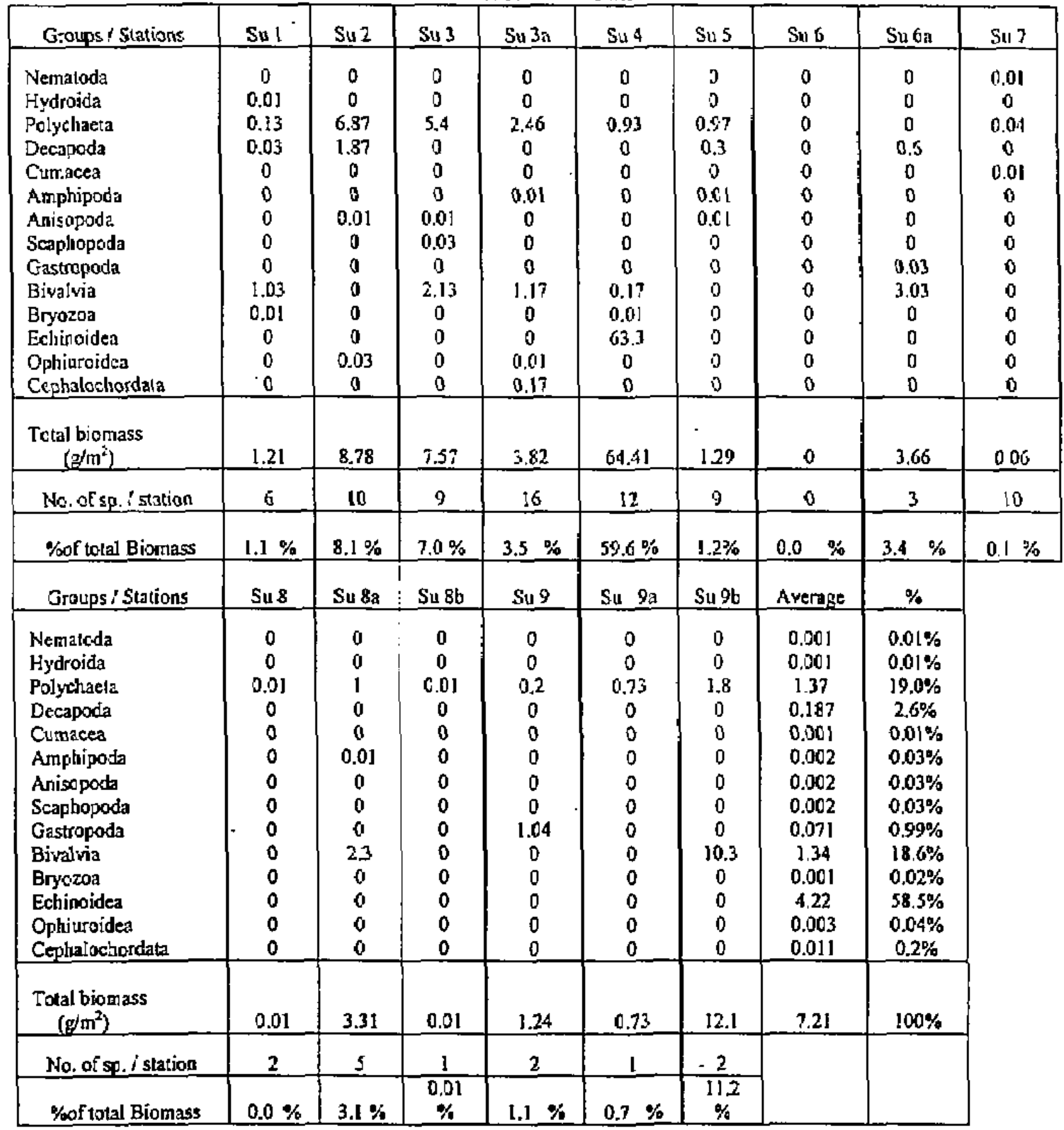




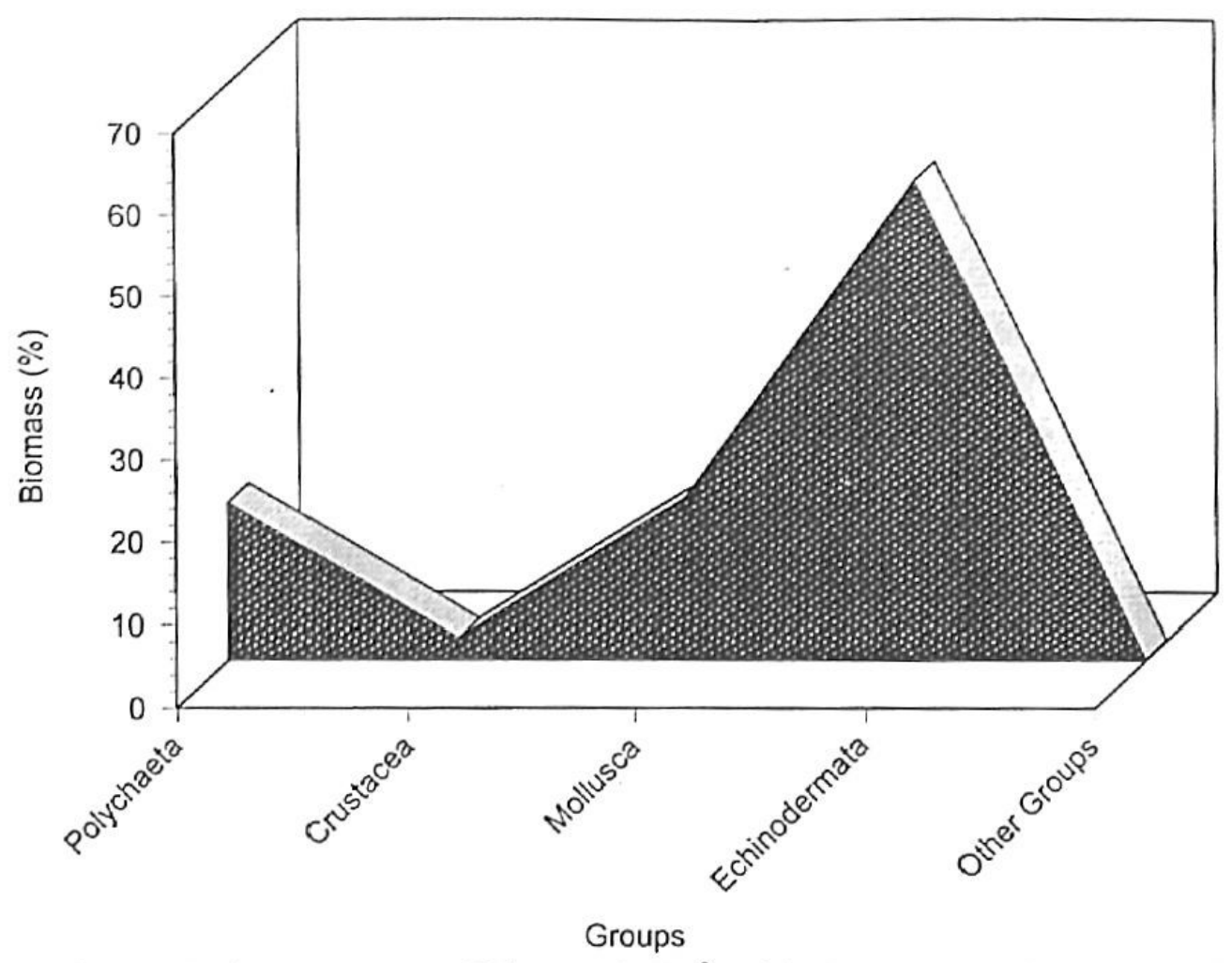

Fig. (6): Variations in the percentage of biomass $\left(\mathrm{g} / \mathrm{m}^{2}\right)$ of the bottom sampling at the different sites along the western coast of Suez Gulf during 2000.

The percentage of biomass of benthic groups at higher taxonomic levels (Table 4) at the different sampling sites can also be ranked as following: echinoderms $(58.60 \%)>$ molluscs $(19.60 \%)>$ polychaetes $(19.0 \%)>$ crustaceans $(2.67 \%)>$ other groups $(0.19 \%)$.

Regional distribution patterns of benthos:

Regional variations in the species number, abundance and biomass of benthic fauna at all sites were noticed. Values of sample abundance were the highest at sites Su1 (Suez Bay), Su2 (NIOF Suez Bay), Su3 (Suez), Su3a (Suez) and Su5 (Ain Sukhna) representing 137, 422, 480, 221 and 298 ind. $/ \mathrm{m}^{2}$ respectively, as shown in Table (1).

The bivalve species Tellinella staurella had the maximum occurrence at 4 sites, yielding a total of 70 ind $/ \mathrm{m}^{2}$. (57\% of the total bivalves). It was recorded at Su1 (Suez Bay), Su3 (Suez Bay), Su 3a (Suez) and Su 8a (Ras Gharib) comprising 23, 30, 30 and 20 ind. $/ \mathrm{m}^{2}$ respectively.

Polychaete species were more frequent at nearly all sites. The dominant family was Capitellidae, comprising 933 individuals which represented $37.7 \%$ of total density, being recorded at 5 sites namely: Sul (Suez Bay), Su2 (NIOF Suez Bay), Su3 (Suez), Su5 (Ain Sukhna) and Su8a (Ras Gharib). Four species of polychaetes namely Glycera convoluta, Lumbrineries latreilli, Armandia polyphthalima and Notomastus sp. were less frequent at 5 to 6 sites, accounting a 
total of 36 to 69 individuals. These species represented $2.4,2.8,1.5$ and $2.7 \%$ of the total abundance.

Table (4): Regional distributions of groups of benthos biomass $\left(\mathrm{g} / \mathrm{m}^{2}\right)$ at the different sampling sites along the coastal waters of the Gulf of Suez during Oclober, 2000.

Western coast of the Gulf of Suez

\begin{tabular}{|c|c|c|c|c|c|c|c|c|c|}
\hline Groups / Stations & Su 1 & Su 2 & Su 3 & Su 3a & Su 4 & Su 5 & Su 6 & St1 $6 n$ & Su 7 \\
\hline Polycliaeta & 0.13 & 6.87 & 5.4 & 2.46 & 0.93 & 0.97 & 0 & 0 & 0.04 \\
\hline Crustacea & 0.03 & 1.88 & 0.01 & 0.01 & 0 & 0.32 & 0 & 0.6 & 0.01 \\
\hline Mallusca & 1.03 & 0 & 2.16 & 1.17 & 0.17 & 0 & 0 & 3.06 & 0 \\
\hline Echinodermata & 0 & 0.03 & 0 & 0.01 & 63.3 & 0 & 0 & 0 & 0 \\
\hline Other gtoups & 0.02 & 0 & 0 & 0.17 & 0.01 & 0 & 0 & 0 & 0.01 \\
\hline $\begin{array}{l}\text { Tolal biomass } \\
\left(\mathrm{g} / \mathrm{m}^{2}\right)\end{array}$ & 1.21 & 8.78 & 7.57 & 3.82 & 64.41 & 1.29 & 0 & 3.66 & 0.06 \\
\hline No. of sg. $/$ station & 6 & 10 & 9 & 16 & 12 & 9 & 0 & 3 & 10 \\
\hline$\%$ of total Biomass & $1.12 \%$ & $8.13 \%$ & $7.01 \%$ & $3.54 \%$ & $59.64 \%$ & $1.19 \%$ & $0.0 \%$ & $3.39 \%$ & $0.06 \%$ \\
\hline
\end{tabular}

\begin{tabular}{|c|c|c|c|c|c|c|c|c|}
\hline Groups / Stations & - Su 8 & Su $8 a$ & Su $8 b$ & Su 9 & Su9a & Su9b & Average & $\%$ \\
\hline $\begin{array}{l}\text { Polychaeta } \\
\text { Crustacea } \\
\text { Mollusca } \\
\text { Echinodermata } \\
\text { Other groups }\end{array}$ & $\begin{array}{c}0.01 \\
0 \\
0 \\
0 \\
0 \\
\end{array}$ & $\begin{array}{c}1 \\
0.01 \\
2.3 \\
0 \\
0 \\
\end{array}$ & $\begin{array}{c}0.01 \\
0 \\
0 \\
0 \\
0 \\
\end{array}$ & $\begin{array}{c}0.2 \\
0 \\
1.04 \\
0 \\
0 \\
\end{array}$ & $\begin{array}{l}0.73 \\
0 \\
0 \\
0 \\
0 \\
\end{array}$ & $\begin{array}{c}1.8 \\
0 \\
10.3 \\
0 \\
0 \\
\end{array}$ & $\begin{array}{l}1.37 \\
0.19 \\
1.42 \\
1.22 \\
0.01 \\
\end{array}$ & $\begin{array}{l}19.0 \% \\
2.7 \% \\
19.7 \% \\
58.6 \% \\
0.19 \% \\
\end{array}$ \\
\hline $\begin{array}{c}\text { Total biomass } \\
\left(\mathrm{e}^{\prime} \mathrm{m}^{2}\right)\end{array}$ & 0.01 & 3.31 & 0.01 & 1.24 & 0.73 & 12,1 & 7.2 & $100 \%$ \\
\hline No. of sp./ station & 2 & 5 & 1 & 2 & 1 & 2 & & \\
\hline$\%$ of total Biomass & $0.01 \%$ & $3,06 \%$ & $0.01 \%$ & $1.15 \%$ & $0.68 \%$ & $11.20 \%$ & & \\
\hline
\end{tabular}

The cephalochordate, Brachiostoma lanceolatum was represented by 10 ind. $/ \mathrm{m}^{2}$ at Suez (Su3a). The percentage of abundance of the bottom fauna at different sampling sites along the Gulf of Suez can be arranged in the following order: $10-20 \%$ (Su2, Su3, and Su5), 5-10\% (Su1, Su3a) and less than 5\% of the total number of individuals at the remaining sampling sites (Table 1). Also the percentage of biomass of bottom fauna at the sampling sites, (Table 2) can be arranged as follows: $10-15 \%(\mathrm{Su} 4)$ and less than $5 \%$ of the total wet weight of the individuals at the remaining sites.

\section{Analysing of Benthos Community Structure}

Univariate analysis

Species diversity, Evenness, Richness, and Simpson index

Indices of diversity, evenness, richness and dominance are shown in Table (5). The higher diversity was found at Suez (Su3a), Ain Sukhna (Su4), NIOF Suez Bay (Su2), Ras Gharib (Su7) and Suez Bay (Su1) recording 3.274, $2.585,2.396,2.264$ and 2.056 respectively by contrast to others.

Table (5) shows the values of species diversity $\left(\mathrm{H}^{\prime}\right)$, evenness (E), richness of species (J), and Simpson index (D). Suez (Su 3á) had highest 
diversity (3.274), closely followed by sites Su7 (Ras Gharib) and Su4 (Ain Sukhna), ranging from 2.264 to 2.585 . The low species diversity was estimated at the remainder sites, which was primarily attributed to the uneven distribution of individuals among the species.

Pielou's evenness index (E) showed highest values at site Su8, RasGharib (0.88), which can be due to a greater variation among faunal dominance.

The values of Margalef's species richness $(\mathrm{J})$ were maximal at sites Su5, Su2, Su4 and Su3a, being 0.975, 1.032, 1.75 and 1.96 respectively.

The dominance Simpson's index (D) had high value at site Su3a, reaching 0.876 , Fig. (8).

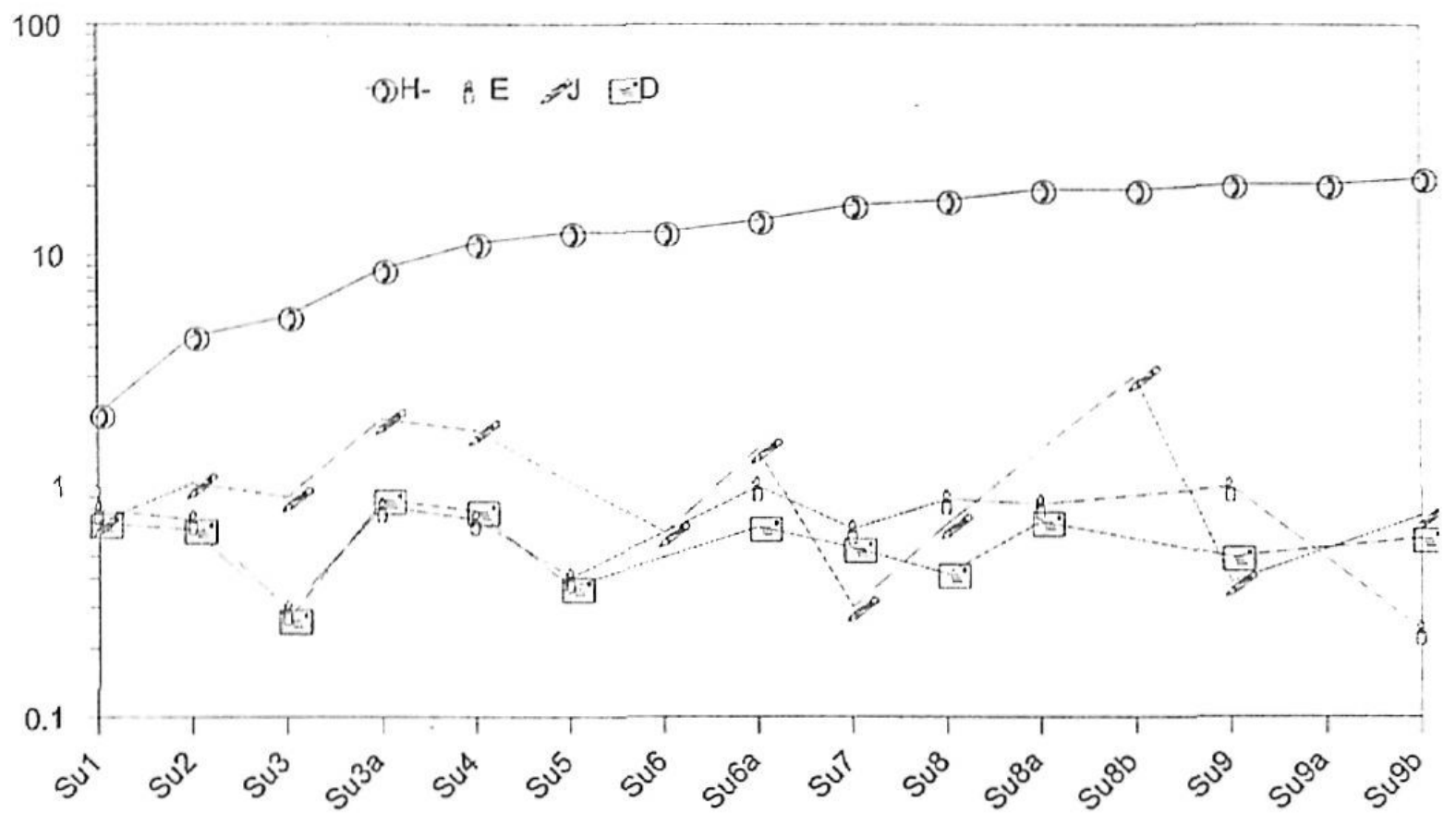

Stations

Fig. (8): Variations of Shannon-Weaver diversity ( $\left.\mathrm{H}^{-}\right)$, Pielou evenness (E), Margalef richness (J) and Simpson index (D) of benthic communities analyses at the different sites of bottom sampling along the western coast of the Gulf of Suez during 2000 .

\section{Ratios of Biomass /Abundance and Abundance / Species}

As shown in Table (5), the ratio of B/A was high at Su 4 (Ain Sukhna) and Su 6a (Abu-Darag), representing 0.83 and 0.41 . However, the highest value of $\mathrm{B} / \mathrm{A}$ ratio reached 0.93 at $\mathrm{Su} 9 \mathrm{~b}$ (Ras-Shukeir), whereas the ratio of $\mathrm{A} / \mathrm{S}$ ratio was high at sites Sul (Suez Bay), Su5 (Ain Sukhna), Su2 (NIOF Suez Bay) and Su3 (Suez Bay) amounting to 22.83, 33.10, 42.2 and 53.3 respectively. The remaining sites had relatively low values, Fig. (3). 
Table (5) : Basic description variables for benthos samplings at the different sites along the coastal waters of the Gulf of Suez during October, 2000.

Western coast of the Gulf of Suez

\begin{tabular}{|l|c|c|c|c|c|c|c|c|c|c|c|}
\hline \multicolumn{1}{|c|}{ Site Name } & St. no. & Bottom & S & B & A & II & E & J & D & B / A & A / S \\
\hline Suez Bay & Su 1 & M.S. & 6 & 1.21 & 1.37 & 2.06 & 0.79 & 0.70 & 0.69 & 0.01 & 22.8 \\
Suez Bay & Nu 2 & M.S. & 10 & 8.78 & 422 & 2.39 & 0.72 & 1.03 & 0.65 & 0.02 & 42.2 \\
Suez Bay & Su 3 & M.S. & 9 & 7.53 & 480 & 0.97 & 0.29 & 0.89 & 0.27 & 0.02 & 53.3 \\
Suez & Su 3a & M.S. & 16 & 3.82 & 221 & 3.27 & 0.82 & 1.96 & 0.85 & 0.02 & 13.8 \\
Ain Suklina & Su 4 & F.S. & 12 & 64.4 & 78 & 2.59 & 0.72 & 1.75 & 0.79 & 0.83 & 6.5 \\
Ain Suklina & Su 5 & Md.S. & 9 & 1.29 & 298 & 1.28 & 0.40 & 0.98 & 0.37 & 0.00 & 33.1 \\
Wady el Dom & Su 6 & F.S. & 0 & 0 & 0 & 0 & 0 & 0 & 0 & 0.00 & 0.0 \\
Abu Darag & Su 6a & M.S. & 3 & 3.79 & 9 & 1.59 & 1 & 0.63 & 0.67 & 0.41 & 3.0 \\
Ras Gharib & Su 7 & C.S. & 10 & 0.05 & 119 & 2.26 & 0.65 & 1.45 & 0.54 & 0.00 & 11.9 \\
Ras Gharib & Su 8 & F.S. & 2 & 0.01 & 10 & 0.88 & 0.88 & 0.30 & 0.42 & 0.00 & 5.0 \\
Ras Gharib & Su 8a & F.S. & 5 & 3.31 & 56 & 1.95 & 0.84 & 0.69 & 0.71 & 0.06 & 11.2 \\
Ras Gharib & Su 8b & M.S. & 1 & 0.01 & 13 & 0 & 0 & 0 & 0 & 0.00 & 13.0 \\
Ras Shukier & Su 9 & F.S. & 2 & 1.24 & 6 & 1 & 1 & 0.39 & 0.5 & 0.21 & 3.0 \\
Ras Shukier & Su 9a & C.S. & 1 & 0.73 & 7 & 0 & 0 & 0 & 0 & 0.10 & 7.0 \\
Ras Shukier & Su 9b & M.S. & 2 & 12.1 & 13 & 1.33 & 0.24 & 0.75 & 0.54 & 0.93 & $\mathbf{6 . 5}$ \\
\hline
\end{tabular}

$\mathrm{H}^{`}$ (Shannon and Wiener index) species diversity $\sum-=P i \log P i$

$\mathrm{E}$ (Evenness) Pielou`s index $=\mathrm{H}^{\prime} / \mathrm{Hmax}$

$\mathrm{J}$ (Richness) Margalef's index) $=S-I) / \log N$

D Simpson index) $\left.\sum-I=P i\right) 2$

C. S. Coarse sand M.S. Medium sand F.S. Fine sand Md. S. Muddy sand $\mathrm{S}=$ No. of species $\quad \mathrm{A}=$ abundance no. ind $/ \mathrm{m}^{2} \quad \mathrm{~B}=$ Biomass $\mathrm{g} / \mathrm{m}^{2}$

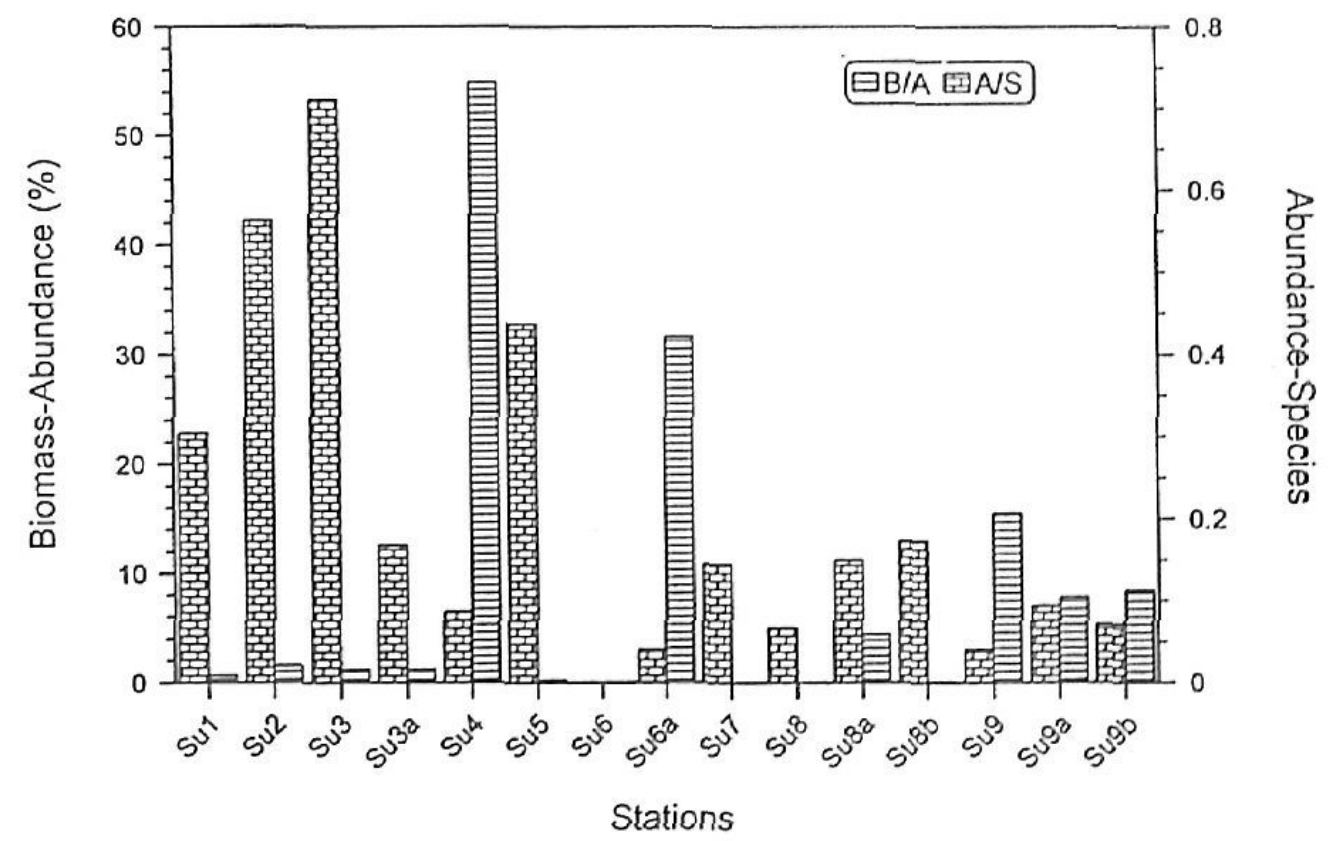

Fig. (3): Abundance/Śpecies and biomass/Abundance ratios of benthic groups recorded at different sampling sites along the western coast of the Gulf of Suez during 2000. 


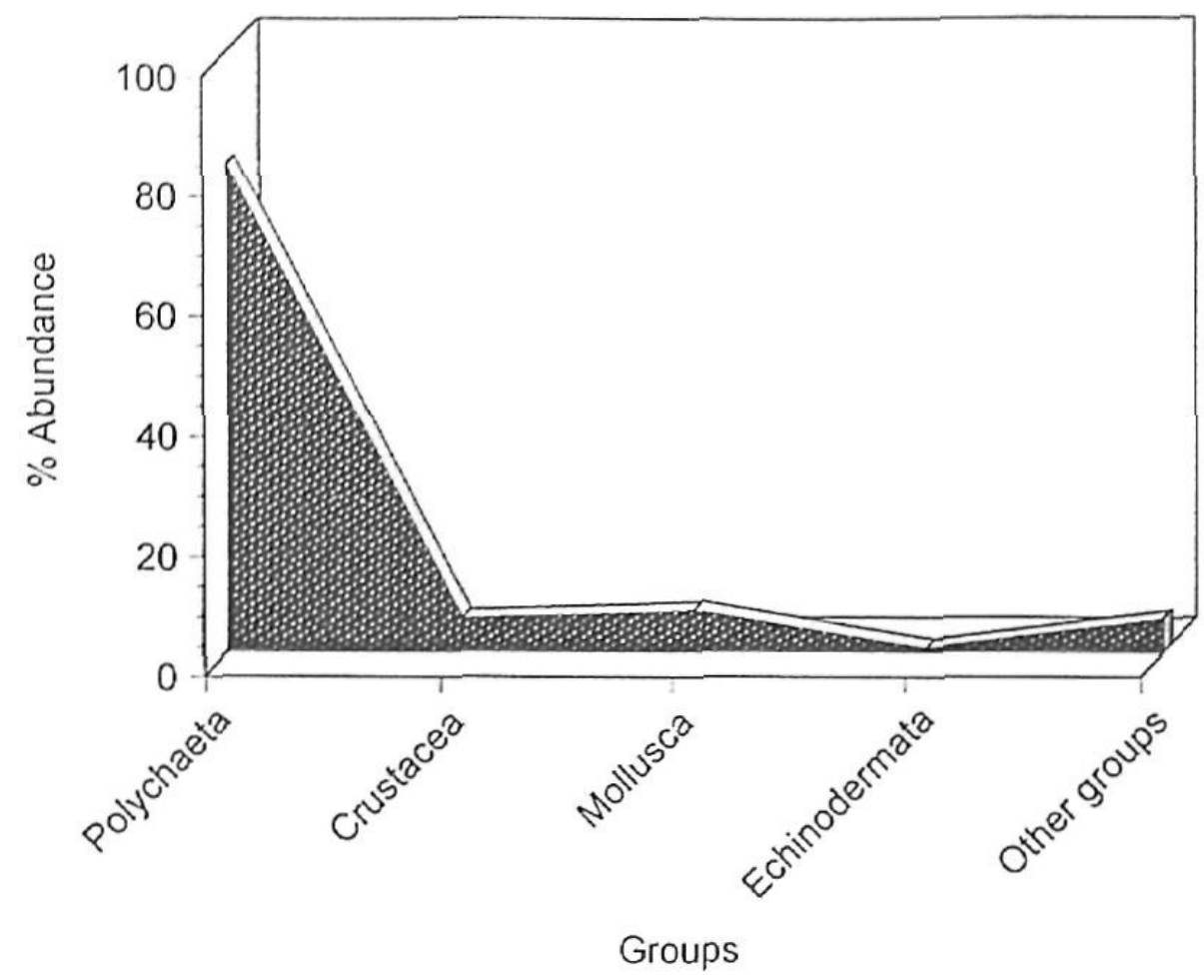

Fig. (5): Variations in the percentage of abundance (no. ind. $/ \mathrm{m}^{2}$ ) of the benthic groups at the different sites along the western coast of Suez Gulf during 2000.

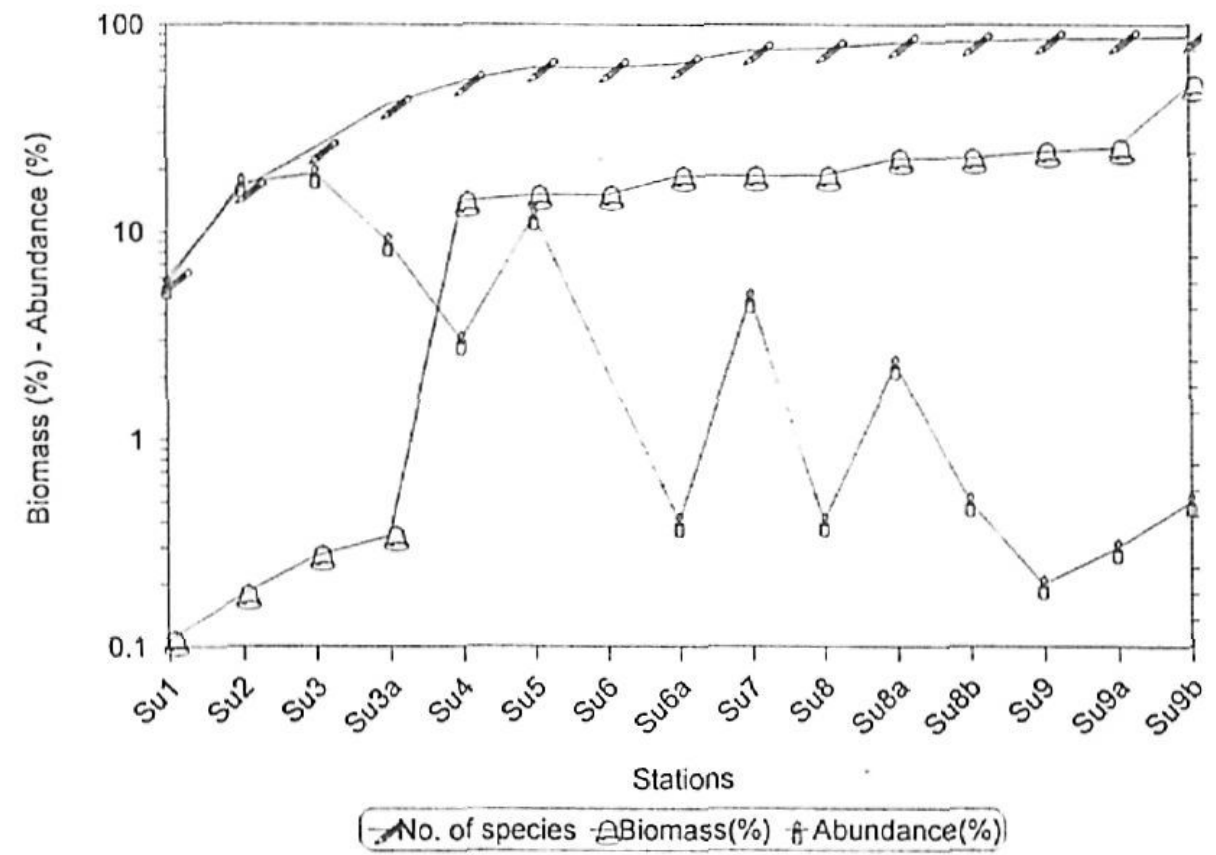

Fig. (7) : Species-Biomass-Abundance logarithmic curves of benthic communities analyses at the different sites of bottom sampling during 2000 . 
Multivariate analysis Abundance-Sites Clustering

Dendrograms based on Euclidean distances for clustering of 15 numerical density variables of all benthos collected at the different sites are shown in Fig. (9). The highest similarity was noticed between two group sites, the $1^{\text {st }}$ group (Su3 and Su2) and the $2^{\text {nd }}$ group (Su5 and Su3a). The two groups showed the highest similarity between 3 Classes, the $1^{\text {st }}$ class included (Su 8 a and Su4), the $2^{\text {nd }}$ class included (Su7 and Sul) and the $3^{\text {rd }}$ class included the remaining sites.

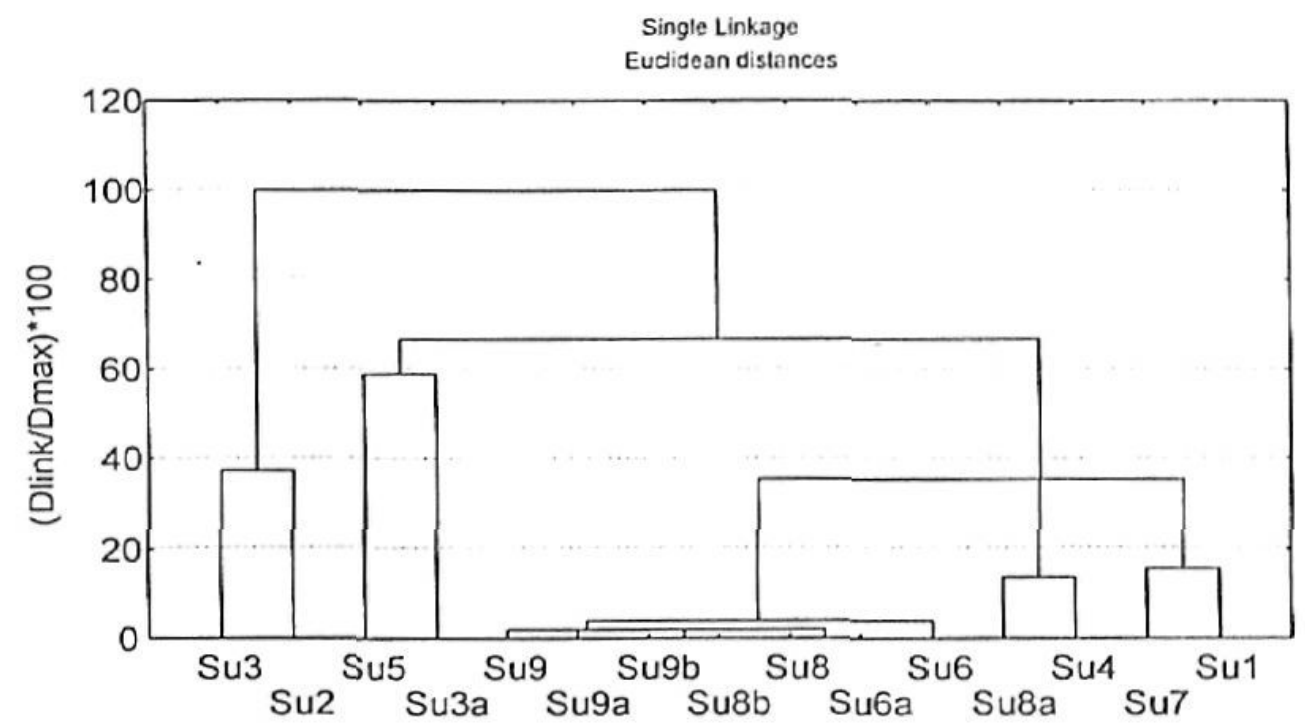

\section{Biomass-Sites Clustering:}

Dendrograms based on the numerical variables of biomass of all benthos data collected at the different sites are plotted in Fig. (10). Three distinct groups showed maximum similarity at Su 4 (Ain Sukhna).

\section{Groups Clustering}

The clustering analysis of the density of the benthic groups recorded at the sampling sites (Fig. 11) showed that Scaphopoda had maximum similarity with Polychaeta, Bivalvia and Gastropoda. The $2^{\text {nd }}$ distinct group was between Nematoda and other groups. 


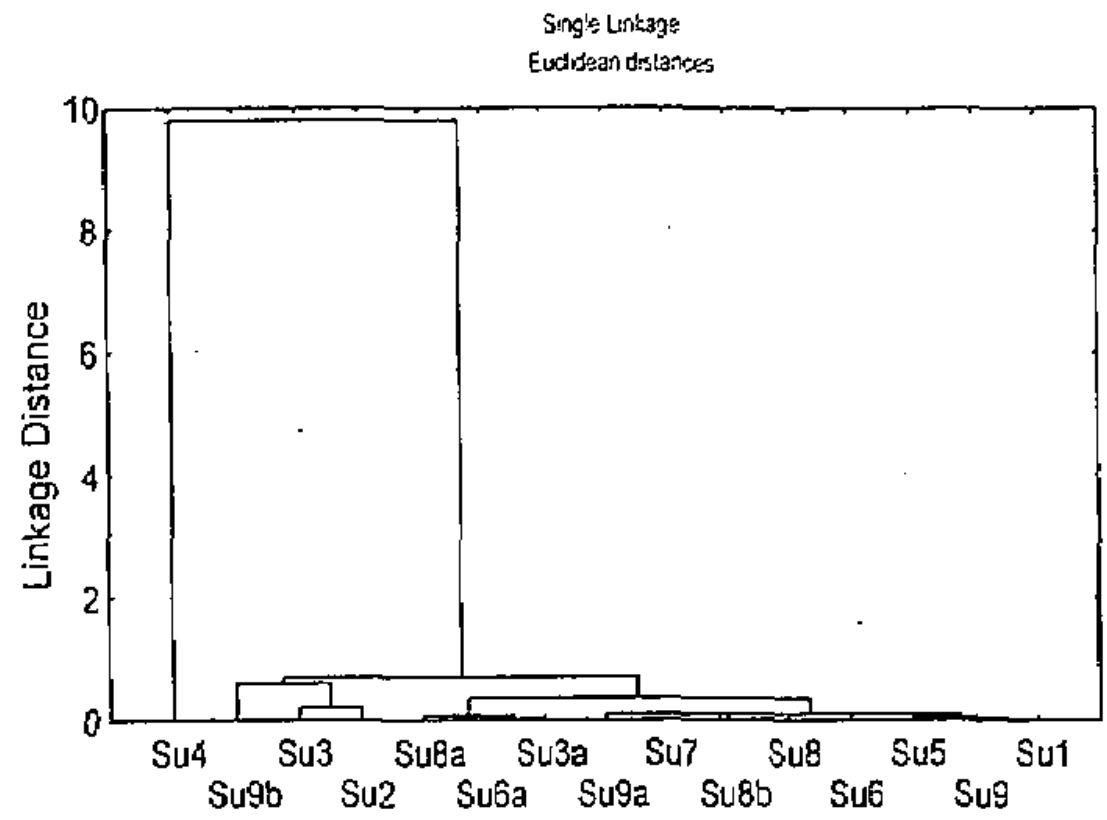

Fig. (10): Cluster analysis diagram for the percentage biomass of the benthos at the different stations along the western coast of the Gulf of Suez during 2000.

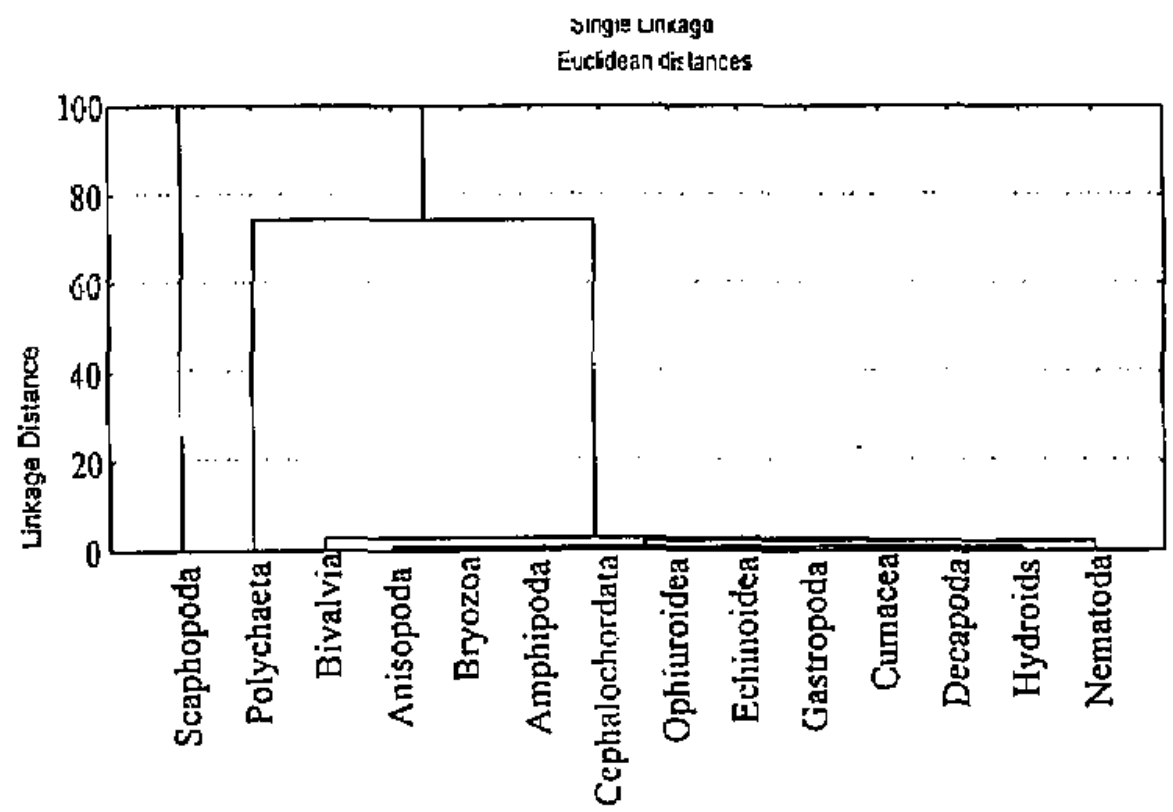

Fig. (11): Cluster analysis diagram for the percentage abundance of the different groups of benthos along the western coast of the Gulf of Suez during 2000 . 
Clustering analysis for the biomass of benthic groups as shown in Fig. (12) reveals noticeable relationship between Echinoidea and three groups. The $1^{\text {s1 }}$ group includes Bivalvia and Polychaeta, the $2^{\text {nd }}$ group includes Decapocia and Gastropoda and the $3^{\text {rd }}$ group involves Anisopoda while the remaining revups showed, the least similarity.

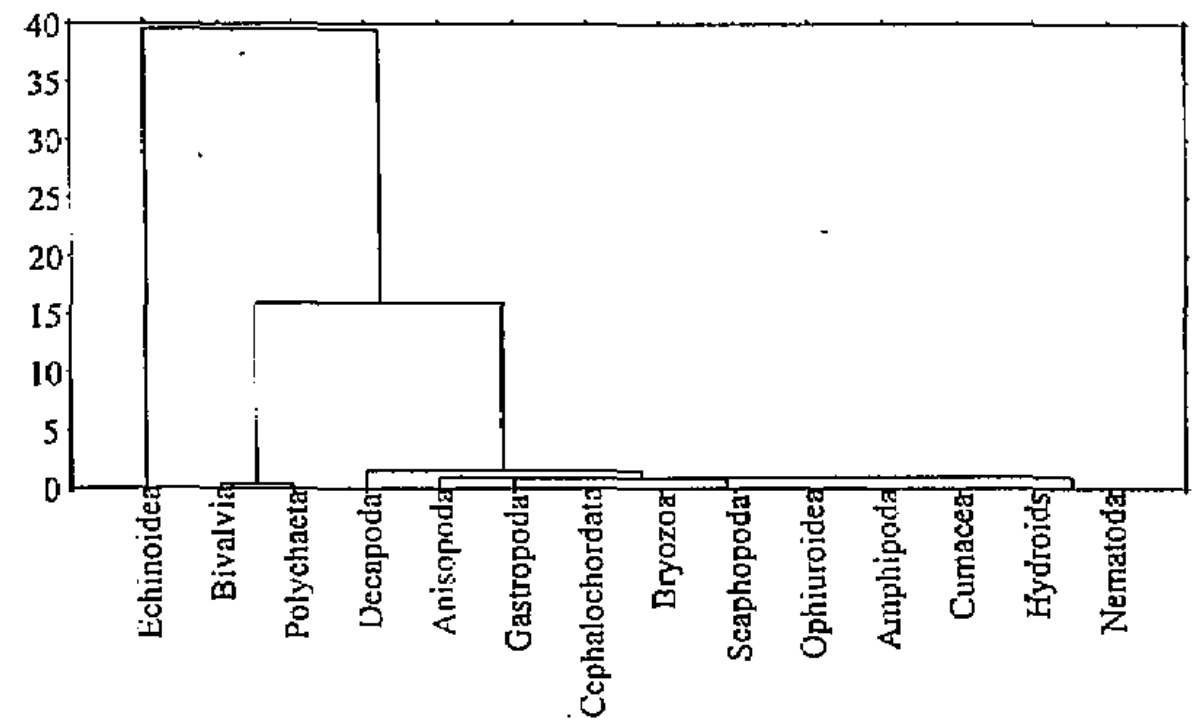

Fig. (12): Cluster analysis diagram for the percentage biomass of the different groups of benthos along the western coast of the Gulf of Suez during 2000.

\section{DISCUSSION}

The benthos is affected by a wide variety of environmental parameters, which can be grouped into physical and biological parameters as well as by pollution. The composition of benthos on a site is determined by a complex interaction of all these parameters. Abbott (1966) related the varying degrees of faunal affinity to the effect of ocean currents, land and sea barriers, thermal conditions, inshore water, timing and duration of spawning seasons and the incidence of larvae capable of prolonged planktonic existence. Pollution can affect benthos in a number of ways: Toxic substances may kill some animals and weaken others, which at the end will result in a change of the benthos community. In severe cases all animals may be killed. The increased loads of organic material can affect the fauna. Based on a substantial amount of data, Pearson and Rosenberg (1978) found a general succession pattern of benthic infauna in response to increased eutrophication and resulting load of organic material to the sediment. Initially, increasing load of organic matter will result in an increase in the number of species, the biomass and density (abundance) of organisms because of the increasing the amount of food for the organisms. 
When the load reaches to a certain level, the number of species, the biomass and the density decline. The reason seems to be related to the oxidized layer of the sediment that becomes thinner because the organic matter consumes oxygen. At very heavy loads, oxygen depletion in the seabed may periodically takes place. Only very few species can tolerate such conditions, so the number of species decreases further as a result. Longer periods of oxygen depletion lead to the extinction of the fauna. When oxygen conditions improve, the area is rapidly recognized by very its few opportunistic species, which may occur in high densities. Therefore seems that the benthos is affected by organic pollution in Suez Bay and at Ain Sukhna. Generally, it seems that the organic load to the sediment have had a stimulating effect on the fauna, with elevated abundance and number of species. There are indications of the fauna being occasionally affected by poor oxygen conditions in the sediments in Suez Bay. If the organic load increases further, there may be a risk of adverse impacts and decreasing abundance and number of species due to oxygen depletion. The silt/clay content of the sediment may however, also influence the composition of the fauna. In general, the benthos in the major part of the Gulf of Suez south of Suez Bay and Ain Sukhna does not seem to be adversely affected by metal pollution.

The sediments at the monitoring stations along the Gulf of Suez Coastline can be ranked witly respect to degree of pollution as follows :

Su $I$ in Suez Bay close to Suez City is the most polluted site

Su 2 and Su 3 in Suez Bay are also quite polluted but to a lesser extent compared to Su 1 .

The stations from Suez Bay to Ain Suklnna (Su3a-Su5) are somewhat polluted by organic matter, but not to an extent that may cause stern to the coastal stretches from Wady El Dom to Ras Shukeir (Su6 - Su 9b) along the West Coast and from Ras Sudr to El Tur (Su10 - Su13a) along Sinai coast. The most poliuted site in the Gulf of Suez is Sul in Suez Bay close to Suez City. Where Copper, lead and zinc markedly affect this site; and so may have adverse impact on its benthos. Moreover, its sediment is heavily affected by eutrophication with high levels of total phosphorous, total nitrogen and organic matter.

The organic load to the sediment has a stimulating effect on the fauna, with elevated abundance of species. However, there are indications of the fauna being occasionally affected by poor oxygen conditions in the sediments in Suez Bay. Decreasing abundance of species due to oxygen depletion. The silt/clay content of the sediment may however, also influence the composition of the fauna.

Approximately 500 animals and plants are listed as being the most typical for the infratidal and shallow subtidal benthic fauna of the Red Sea. Most of them are divided into communities typical for various soft and hard substrata, and at different water depths according to the habitats. The oceanographic condition and the development of several communities are discussed in general terms, (Fishelson, 1971). 
Cacabelos et al. (2005) showed that benthic fauna structure and composition has a strong relationship with sedimentary characteristics and faunal assemblages with low abundances and low number of species recorded on northern sites of the Galician coast with dominance of medium sand fraction.

The northern side of the Gulf of Suez is receiving heavy load of the waste water from industrial sources (mainly petrochemicals, fertilizers, power station, etc.) and sewage effluents. The midwestern side is located under the ditect effect of sewage and petrochemical effluents of Ras-Gharib city, whereas the human impacts of the eastern (Sinai Peninsula) and the southern (El-Tour city) sides are still insignificant due to the low population there. However, great and rapid recreational developments have been taken place on these two sides in addition to El-Sukhna new harbor, recently established in the northwestern side of the Gulf. Accordingly, Environment Information and Monitoring Programme (EIMP) has been established to assess the oethetic quality of the Gulf of Suez coastal waters to initate monitoring and data base system using, quality control and quality assurance work and for sustainable use and development of Suez Gulf coasline. So, Fahmy et al. (2006) concluded that, hydrochemical parameters (water temperature, salinity, dissolved oxygen, $\mathrm{pH}$ and transparency besided with chlorophyll-a, total suspended matter) and nutrient salts (nitrogen, phosphorus and reactive silicate) were investigated as indicators for water quality criteria of the Gulf. The obtained data signified that, the northern side of the Gulf is located under stress due to the relative high concentrations of ammonium, nitrate, nitrite, total suspended matter and chlorophyll-a. The condition at this part is highly eutrophic. This is completely different from that found in other parts of the Gulf, which are fluctuating between oligotrophic to mesotrophic state like that of the proper Red Sea waters.

The sediments in the Suez Bay farther away from Suez City at Su2 and Su3 are polluted, but to a much lesser extent compared to Sul. Eutrophication and high organic loads affect the sediments. They are also slightly polluted by lead that poses a slight risk of toxic effects. As the case at Sul, the benthos is affected by the high organic load and possibly oxygen depletion. Toxic concentrations of $\mathrm{Cd}, \mathrm{Cu}, \mathrm{Pb}$ and $\mathrm{Zn}$ are not found at any of the remaining sites in the Gulf of Suez, not even along the stretch from Abu Zenima to El Tur on the East Coast, where elevated concentrations of $\mathrm{Cd}$ are found. The benthos is affected by eutrophication at Ain Sukhna, but in open Gulf of Suez, it does not seem to be adversely affected by pollution.

Data analyses obtained from the present monitoring program are contradicting the stress effluent of various pollutant sources in particular near the oil production areas of the western coast of the Suez Gulf (Su 7, Ras Gharib; Su 9, Ras Shukier); oil transportation and waiting vessels area (Su 1, Suez Bay, Su 4, Ain Sukhna). Because the species diversity and benthic densities obviously remained constant at the different sampling sites, their regional distribution of benthos showed similarity complex results, with no simple relationships between 
disturbance intensity and pollutant impacts on bottom fauna. However, there was directional trend for benthic populations, which may have maximum impact at intermediate disturbance levels. This estimation for the impacts of the environmental stern was based only on the three bottom sediments collections using van Veen grab sampler. So we did not take "benthic patches" into consideration which could increase the real biodiversity, depending on the numerical abundance and species composition of various benthic populations within patches. The benthic mobile individuals reflect any disturbance on regional distribution of macobenthic communities at a certain ecosystem area. The numerical density of benthos per square meter was significantly lower (ranged from 6 to 480 ind $/ \mathrm{m}^{2}$ ), reflecting a general pattern of lower bottom invertebrates densities at the different sampling sites. This variation in densities is due mainly to the structure of substrata, where there were no variations between the qualities of sediment to the number and biomass of benthic groups.

Our results do not clearly support that impacts of undesirable environment conditions should explain the trend for reduced benthic biodiversity and numerical abundance of benthic communities. Furthermore, experimental studies on the impact of different a biotic factors prevailing in the coastal region are needed besides field surveys to determine the relative tolerable levels where benthic densities were either unclianged or reduced due variable discharges, into sea water. These data provide evidence of increased or decreased resistance rates of common benthic populations in certain area of study due to variable concentrations of experimental treatments. Such leval of resistance to certain pollutants seems too be varied greatly among different benthic species as well in different sites.

\section{REFERENCES}

Abbott, D.P. (1966). Factors influencing the zoogeographic affinities of the Galapagos-inshore marine fauna. Proceedings of the Symposium on Galapagos International Scientific Projects, pp 108-122.

Badr, A.M. and Crossland, C. (1939). Topography of the Red Sea floor. Reports on the preliminary exploration of the Red Sea, Publication Marine Biological Station Ghardaqa (Red Sea), 1: 13-20.

Bilyard, G.R. (1987). The value of benthic infauna in marine condition monitoring studies. Mar. Po[lut. Bull. 18: 581-585.

Cacabelos, E.; Dominguez, M.; Gestoso, A.; Lourido, P.; Quintas, J.; Moreira, J. and Troncoso, J. (2005). Macrobenthic communities in soft bottoms of the Galician coast. Situation six months after the Prestige oil- spills. Departarnento de Ecoloxia e Bioloxia Animal. Facultade de Ciencias do 
mar. Campus de lagoas-Marcosende. Universidade de Vigo. 36310, Vigo Espana.

EIMP (2000). Final Report on Sediments, Biota and Benthos from Coastal Areas of the Gulf of Suez and Mediterranean Sea during 1999. pp. 59, plus, 21 tables, 31 figures, and 2 appendix tables.

El-Komi, M.M. (1997). A preliminary list of the summer macrobenthos in the intertidal zone of the western Gulf of Suez. Bull. Inst. Oceanogr. and Fish. ARE, 23: 295-314.

El-Komi, M.M. - and Beltagy A.I. (1997). Distribution of macrobenthos assemblages in the north coast of Egypt. Bull. Inst. Oceanogr. and Fish. ARE, 23: 267-293

Fahmy, M.A.; Shreadah, M.A.; Abo El-Khair, E.M.; Abdel Halim, A.M.; Abo El-Soud, A. and Abdel Rahman, S.M. (2006). Chemistry of the Gulf of Suez coastal waters, Red Sea, Egypt. International Conference on Aquatic Resources: Needs and Benefits, September 18-21 ${ }^{\mathrm{sl}}, 2006$, Alexandria, Egypt.

FAO (1991). Lecture notes prepared for the training workshop on the statistical treatment and interpretation of marine community data. Athens, $196 \mathrm{pp}$.

Fishelson, L. (1971). Ecology and distribution of the benthic fauna in the sliallow waters of the Red Sea. Marine Biology, 10: 113-133.

Hargrave, B.T. and Thiel, H. (1983). Assessment of pollution-induced changes in benthic community structure. Marine Pollution Bull., 14: 41-46.

Hartnail, R.G. (1984). Problems in the assessment and discrimination of nature and anthropogenic changes in coral reef communities. Proceeding of the Symposium on coral reef Environment of the Red Sea, Jeddah, January $14-18,1984,394-414$.

Kenny, A.J. and Rees, H.L. (1994). The effects of marine gravel extraction on the mácrobenthos. Early post-dredging recolonization. Mar. Pollut. Bull., 28: 442-447.

Margalef R. (1958). Information theory in ecology. Gen. Syste., 3: 36-71. 
Nawar, A.H. (1981). Bottom sediments and topography of the Gulf of Suez. Bulletin of the National Institute of Oceanography and Fisheries ARE, $7(3): 484-504$.

Pearson, T.H. and Rosenberg, R. (1978). Macrobenthic succession in relation to organic enrichment and pollution of the marine environment. Oceanogr. Mar. Biol. Ann. Rev., 16: 229-241.

ielou, C. (1966). The measurement of diversity in different types of biological collections. J. Theor. Biol., 13: 131-144.

Shannon, C.E. and Weaver, W. (1949). The mathematical theory of communities. University of Illinois Press: $117 \mathrm{pp}$.

Simpson, H. (1949). Measurement of diversity. Nature, 163: 688. 